DOI: https://doi.org/10.24127/ajpm.v9i1.2443

\title{
EFEKTIFITAS PENGGUNAAN MODUL MATEMATIKA DASAR PADA MATERI BILANGAN TERHADAP HASIL BELAJAR
}

\author{
Rahma Ramadhani ${ }^{1}$, Abdiyah Amudi ${ }^{2}$ \\ ${ }^{1,2}$ Universitas Hasyim Asy'ari, Tebuireng Jombang, Indonesia \\ E-mail: $\quad$ madhasmart@gmail.com ${ }^{\text {l) }}$ \\ abdiyah.amudi@gmail.com $^{2)}$
}

Received 29 October 2019; Received in revised form 24 January 2020; Accepted 28 March 2020

\begin{abstract}
Abstrak
Penelitian ini bertujuan untuk mengetahui keefektifan dari penggunaan modul matematika dasar kontekstual pada materi bilangan. Objek penelitian adalah 30 mahasiswa yang menempuh matakuliah matematika dasar. Metode penelitian yang digunakan adalah metode kuantitatif serta menggunakan One Group Pretest-Posttest Design. Uji yang dilakukan adalah $n$-gain, uji normalitas, uji homogenitas serta uji T-test (Paired Sample T-Test). Hasil penelitian menunjukkan bahwa keefektifan penggunaan modul perhitungan $n$-gain adalah 0,61 dikategorikan sedang. Uji normalitas dengan Kolmogorov-Sminorv menunjukkan signifikan 0,200 (pretest), 0,092 (posttest), 0,200 (gain), dan 0,200 (n-gain) yang menunjukkan signifikansi > 0,05 (berdistribusi normal). Uji homogenitas dengan Lavene test menunjukkan signifikansi rata-rata 0,98 > 0,05 (homogen). Rata-rata nilai kelas sebelum dan sesudah penggunaan modul naik dari 61,13 menjadi 85,13 dengan uji Paired Sample T-Test diperoleh tingkat signifikansi $0,00,<0,05$ (efektif). Hasil uji lapangan menunjukkan bahwa pemberian modul matematika dasar kontekstual materi bilangan efektif meningkatkan hasil belajar mahasiswa dengan kategori peningkatan "sedang".
\end{abstract}

Kata Kunci; Matematika dasar; efektifitas; hasil belajar; modul; bilangan

\begin{abstract}
This study aims to determine the effectiveness of the use of basic mathematic modules based on contextual at the chapter of numbers. The research object were 30 students who took basic mathematics courses. The research method used is a quantitative method and use One Group Pretest-Posttest Design. Tests performed are n-gain, normality test, homogeneity test and T-test (Paired Sample T-Test). The results showed that the effectiveness of using the n-gain calculation module was 0.61 categorized as moderate. The normality test with Kolmogorov-Sminorv showed significant 0.200 (pretest), 0.092 (posttest), 0.200 (gain), and 0.200 (n-gain) which showed normal distribution. Homogeneity test with Lavene test showed the average significance of $0.98>0.05$ (homogeneous). The average grade before and after the use of the module increased from 61.13 to 85.13 with the Paired Sample T-Test obtained a significance level of $0.00,<0.05$ (effective). The result show that the provision of contextual basic mathematics modules of chapter of number effectively improves student learning outcomes with the category of "moderate" improvement.
\end{abstract}

Keywords: basic mathematic; effectiveness;learning outcomes; module; number

\section{PENDAHULUAN}

Matematika merupakan salah satu ilmu yang penting untuk dipelajari tidak hanya oleh matematikawan akan tetapi juga oleh seseorang yang berkecimpung di bidang lain seperti bidang kedokteran, keteknikan, ekonomi, IT dan lainnya. Tidak semua bagian dari ilmu matematika diperlukan oleh seseorang yang menekuni masingmasing bidang. Dengan demikian, pengetahuan matematika perlu disesuaikan dengan kebutuhan bidang yang ditekuni.

Teknik sipil adalah salah satu bidang yang erat kaitannya dengan 
matematika. Matematika dalam bidang teknik sipil diperlukan seperti materi trigononometri digunakan dalam survei pemetaan, menghitung beban struktural, kemiringan atap dan sebagainya. Materi persamaan diferensial digunakan untuk pemodelan aliran fluida. Matriks digunakan pada materi struktur. Integral digunakan untuk menentukan lendutan dan rotasi serta masih banyak lagi aplikasi matematika yang lain dalam teknik sipil.

Beberapa penelitian sebelumnya seperti penelitian Pratama, Ashadi, \& Indriyanti (2017), Wahyuningrum (2019), Gunawan \& Widayat (2014), Pahriah \& Hendrawani (2018), serta Badawi \& Qaddafi (2015) melakukan penelitian mengenai efektifitas modul. Namun, dari beberapa penelitian sebelumnya belum ada yang meneliti mengenai efektifitas modul matematika dasar yang kontekstual dengan program studi teknik sipil. Dalam penelitian ini, selain mengukur efektifitas dengan uji T-test, juga dilakukan uji $\mathrm{N}$-gain untuk melihat kriteria tingkat kenaikan hasil belajar berdasarkan $N$-gain dengan desain penelitian yang digunakan adalah One Group Pretest-Posttest Design.

Bilangan merupakan konsep matematika yang digunakan dalam perhitungan teknik sipil. Berdasarkan pengamatan, sebagian besar mahasiswa masih mengalami kesulitan dalam melakukan operasi serta menentukan hasil dari operasi bilangan. Mahasiswa masih banyak yang melakukan kesalahan baik perhitungan, konsep maupun prosedural dalam mengerjakan soal bab bilangan (Sari, 2018).

Buku teks yang tersedia masih memerlukan buku ajar pendamping untuk membantu mahasiswa dalam memahami materi matematika teknik. Keberadaan buku teks kurang memberikan motivasi kepada peserta didik (mahasiswa) (Melisa, 2015). Selain itu, banyak buku teks yang menyajikan materi yang tidak terstruktur. Hal tersebut akan mempengaruhi ketercapaian pembelajaran matakuliah dalam suatu program studi.

Oleh karena itu, diperlukan bahan ajar yang sesuai kebutuhan peserta didik. Salah satu bahan ajar yang dapat memenuhi kebutuhan peserta didik yaitu modul. Modul yang digunakan dalam penelitian ini memunculkan keterkaitan matematika dalam bidang teknik sipil (kontekstual). Modul memiliki komponen yang lebih lengkap dibandingkan dengan bahan ajar lain seperti LKS, handout dan bahan ajar lainnya (Yerimadesi, Putra, \& Ririanti, 2017). Modul dapat menuntun mahasiswa untuk belajar secara mandiri. Selain itu, komponenkomponen yang terdapat dalam modul memungkinkan mahasiswa untuk mengukur kemampuan masing-masing serta dapat mempelajari modul sesuai kecepatan belajar masing-masing. Dengan adanya modul matematika teknik ini diharapkan dapat meningkatkan motivasi dan minat dalam belajar matematika teknik yang menjadi salah satu dasar dari teknik sipil. Selain itu, modul juga dapat memenuhi kebutuhan mahasiswa mengenai pemahaman konsep matematika dasar untuk teknik serta aplikasi dalam bidang teknik sipil.

Dengan melihat efektifitas dari modul matematika pada materi bilangan yang telah dikembangkan diharapkan menjadi bahan pertimbangan untuk dapat menjadikan modul tersebut sebagai bahan ajar yang dapat dipakai dalam pembelajaran matematika dasar di teknik sipil. Oleh karena itu, penelitian ini bertujuan untuk mengetahui keefektifan dari 
penggunaan modul matematika dasar kontekstual pada materi bilangan.

\section{METODE PENELITIAN}

Penelitian dilakukan dengan penggunaan modul matematika yang kontekstual dalam bidang teknik sipil sebagai bahan ajar pada materi bilangan. Objek penelitian adalah 30 mahasiswa yang menempuh Matematika Dasar di Program Studi Teknik Sipil Universitas Hasyim Asy'ari Tebuireng Jombang. Penelitian ini merupakan penelitian kuantitatif dengan desain penelitian menggunakan One Group Pretest Posttest Design seperti Gambar 1.

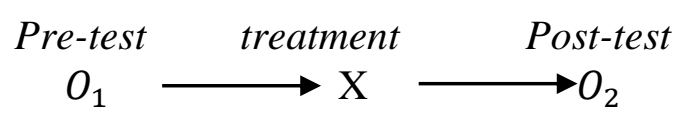

Gambar 1. Desain penelitian

$\begin{array}{ll}\text { Gambar } & 1 \text { menjelaskan bahwa } \\ \text { penelitian } & \text { dilakukan dengan }\end{array}$ menggunakan satu kelas. Pada tahap awal mahasiswa diberikan tes awal (pre-test) untuk mengetahui kemampuan awal mahasiswa pada materi bilangan sebelum diberikan modul. Hasil pre-test digunakan untuk mendapatkan rata-rata nilai (hasil belajar) mahasiswa sebelum penerapan modul. Pada tahap selanjutnya menerapkan bahan ajar berupa modul bilangan. Setelah penerapan modul, selanjutnya diberikan tes akhir (posttest). Hasil post-test digunakan untuk mendapatkan rata-rata nilai (hasil belajar) mahasiswa setelah penggunaan modul.

Setelah diperoleh nilai tes awal dan tes akhir kemudian dianalisis dengan menggunakan $N$-gain dan uji $T$ test untuk melihat keefektifan modul. Instrumen yang digunakan dalam penelitian berupa angket untuk mendapatkan saran dan respon dari responden dan soal pre-test dan posttest untuk mengetahui nilai pre-test (sebelum penggunaan modul) dan nilai post-test (sesudah penggunaan modul).

Adapun hipotesis dalam penelitian adalah sebagai berikut:

$H_{0}$ : tidak ada perbedaan signifikan sebelum dan sesudah penggunaan modul.

$H_{1}$ : ada perbedaan signifikan sebelum dan sesudah penggunaan modul.

Uji yang dilakukan antara lain:

1. Uji gain dan $N$-gain untuk melihat kategori peningkatan sebelum dan sesudah penggunaan modul matematika dasar materi bilangan. Adapun rumus yang digunakan untuk melihat gain adalah

gain $=($ nilai posttest $)-($ nilai pretest $)$ Sedangkan untuk uji $N$-gain menggunakan rumus berikut.

$N-$ gain $(g)=\frac{\text { nilai }_{\text {posttest }}-\text { nilai }_{\text {pretest }}}{\text { nilai }_{\text {max }}-\text { nilai }_{\text {pretest }}}$

Besarnya keefektifan modul pembelajaran (faktor g) berdasarkan kriteria N-gain (Meltzer, 2002) adalah pada Tabel 1 .

Tabel 1. Kriteria $N$-gain

\begin{tabular}{cc}
\hline N-gain & Kriteria \\
\hline $0,7 \leq N$-gain $\leq 1$ & Tinggi \\
$0,3 \leq N$-gain $<0,7$ & Sedang \\
$N$-gain $<0,3$ & Rendah \\
\hline
\end{tabular}

2. Uji normalitas dengan IBM SPSS Statistic 25 melalui hasil Kolmogorov-Smirnov sebagai uji prasyarat untuk Paired Sample T-test untuk mengetahui normalitas data hasil pre-test-post-test, gain, dan $N$ gain.

3. Uji homogenitas melalui dengan IBM SPSS Statistic 25 melalui Lavene Test sebagai uji prasyarat 
DOI: https://doi.org/10.24127/ajpm.v9i1.2443

untuk Paired Sample T-test untuk mengetahui homogenitas data pretest dan post-test.

4. Uji Paired Sample T-test untuk mengetahui apakah ada perbedaan yang signifikan rata-rata nilai antara sebelum dan sesudah penggunaan modul matematika dasar materi bilangan.

Sebelum melakukan T-test terlebih dahulu dilakukan uji normalitas data menggunakan Kolomogorof Smirnov dan uji homogenitas menggunakan Lavene Test. Jika hasil dari uji normalitas Kolmogorof Smirnov memiliki signifikansi > 0,05 maka nilai pre-test dan post-test berdistribusi normal. Namun jika signifikansi $<0,05$ maka nilai pre-test dan post-test tidak normal. Jika uji Lavene test menunjukkan signifikansi > 0,05 maka nilai pre-test dan post-test homogen. Jika signifikansi $<0,05$, maka nilai pre- test dan post-test tidak homogen. Setelah memenuhi persyaratan normalitas dan homogenitas kemudian dilakukan uji T-test (Paired Samples Ttest). Jika signifikansi hasil Paired Samples $T$-test $<0.05$, maka $H_{0}$ ditolak dan menerima $H_{1}$.

\section{HASIL DAN PEMBAHASAN}

Modul yang digunakan dalam penelitian ini merupakan modul yang dikembangkan dengan materi yang kontekstual dengan bidang teknik sipil. Penelitian dilakukan pada materi bilangan yang merupakan materi awal dan pengantar dalam matematika teknik untuk teknik sipil Universitas Hasyim Asy'ari Tebuireng Jombang. Data untuk melihat keefektifan penggunaan modul dilihat melalui nilai pre-test dan posttest. Tabel 2 merupakan hasil dari pretest dan post-test penggunaan modul matematika dasar materi bilangan.

Tabel 2. Hasil pre-test dan post-test penggunaan modul

\begin{tabular}{lccccccc}
\hline No & $\begin{array}{c}\text { Jenis } \\
\text { Tes }\end{array}$ & $\begin{array}{c}\text { Jumlah } \\
\text { Mahasiswa }\end{array}$ & $\begin{array}{c}\text { Rata- } \\
\text { rata }\end{array}$ & $\begin{array}{c}\text { Standar } \\
\text { Error }\end{array}$ & $\begin{array}{c}\text { Standar } \\
\text { Deviasi }\end{array}$ & $\begin{array}{c}\text { Nilai } \\
\text { Minimum }\end{array}$ & $\begin{array}{c}\text { Nilai } \\
\text { Maksimum }\end{array}$ \\
\hline 1 & Pretest & 30 & 61,13 & 1,682 & 9,213 & 42 & 78 \\
2 & Postest & 30 & 85,13 & 1,266 & 6,937 & 72 & 98 \\
\hline
\end{tabular}

Berdasarkan Tabel 2 diketahui bahwa rata-rata nilai pre-test sebelum penggunaan modul adalah 61,13 dengan standar deviasi sebesar 9,123. Nilai minimum pada pre-test adalah 42 , sedangkan nilai maksimum adalah 78 . Rata-rata post-test setelah penggunaan modul adalah 85,13 dengan standar deviasi sebesar 6,937. Nilai minimum pada post-test adalah 72 sedangkan nilai maksimum post-test adalah 98.

Kemudian mencari gain dari nilai pre-test dan post-test masing-masing mahasiswa dan diperoleh persentase untuk masing-masing kriteria (rendah, sedang, dan tinggi) pada Tabel 3.

Tabel 3. Persentase kriteria gain

\begin{tabular}{cc}
\hline $\begin{array}{c}\text { Kriteria } \\
\text { Gain }\end{array}$ & Persentase mahasiswa \\
\hline Rendah & $3,33 \%$ \\
Sedang & $73,33 \%$ \\
Tinggi & $23,34 \%$ \\
\hline
\end{tabular}

Tabel 3 menunjukkan bahwa mahasiswa yang berada pada kriteria gain rendah sebanyak $3,33 \%$, kriteria 
DOI: https://doi.org/10.24127/ajpm.v9i1.2443

sedang sebanyak 73,33\%, dan kategori tinggi

sebanyak 23,34\% dari jumlah semua mahasiswa.

Tabel 4. Kriteria $N$-gain pre-test dan post-test.

\begin{tabular}{lllll}
\hline \multirow{2}{*}{ Data } & $\mathbf{N}$ & \multicolumn{2}{c}{ Rata-rata } & \\
\cline { 3 - 4 } & & Gain & $\begin{array}{c}\boldsymbol{N} \text { - } \\
\text { gain }\end{array}$ & Kategori \\
\hline $\begin{array}{l}\text { Nilai pre- } \\
\text { test dan }\end{array}$ & 30 & 24 & 0,61 & Sedang \\
post-test & & & & \\
\hline
\end{tabular}

Berdasarkan hasil pre-test dan post-test dapat diketahui besaran capaian keefektifan penggunaan modul melalui gain ternormalisasi ( $N$-gain). Dari hasil perhitungan dapat diperoleh rata-rata sebagaimana Tabel 4 yaitu 0,61 artinya efektifitas modul berada pada kategori sedang.

Setelah didapatkan $N$-gain ternomalisasi, sebelum diuji dengan uji T-test (Paired sample T-Test), nilai pretest dan post-test diuji normalitas dan homogenitas terlebih dahulu. Hasil uji normalitas rata-rata nilai pre-test, posttest, gain dan $N$-gain dengan menggunakan uji normalitas Kolmogorov-Smirnov pada Tabel 5.

Tabel 5. Uji normalitas pre-test, posttest, gain, dan $N$-gain

\begin{tabular}{cccc}
\hline No & $\begin{array}{c}\text { Sumber } \\
\text { Data }\end{array}$ & Sig* & Keterangan \\
\hline 1 & Pretest & 0,200 & Normal \\
2 & Posttest & 0,092 & Normal \\
3 & Gain & 0,200 & Normal \\
4 & $N$-gain & 0,200 & Normal \\
\hline$*=$ signifikan level 0,05 &
\end{tabular}

Kriteria pengujian dari normalitas data menggunakan SPSS adalah jika signifikansi > 0,05 maka data dinyatakan berdistribusi normal.
Sedangkan jika signifikansi $<0,05$, maka data tidak berdistribusi normal. Dari tabel 5 menunjukkan bahwa nilai pretest, posttest, gain dan $N$-gain memiliki nilai signifikan $>0,05$ sehingga dinyatakan berdistribusi normal.

Selanjutnya dilakukan uji homogenitas menggunakan Lavene Test untuk melihat apakah data merupakan data homogen atau bukan. Hasil Lavene test pada Tabel 6 .

Tabel 6. Uji homogenitas pre-test dan post-test.

\begin{tabular}{cccc}
\hline $\begin{array}{c}\text { Jenis } \\
\text { Data }\end{array}$ & $\begin{array}{c}\text { Jenis Uji } \\
\text { Homogenitas }\end{array}$ & Sig* & Keterangan \\
\hline Hasil & Lavene Test & 0,98 & Homogen \\
pretest & & & \\
dan & & & \\
postest & & & \\
\hline
\end{tabular}

Jika signifikansi > 0,05 maka data dinyatakan homogen. Sedangkan jika signifikansi $<0,05$, maka data tidak homogen. Dari Tabel 6 diketahui bahwa hasil uji homogenitas dengan Lavene Test menunjukkan bahwa signifikansi dengan menggunakan Lavene Test adalah 0,98. Oleh karena 0,98>0,05 maka data hasil pre-test dan post-test merupakan data homogen.

Setelah data dinyatakan berdistribusi normal serta homogen kemudian menggunakan Paired Sample $T$ Test yang digunakan untuk melihat keefektifan penggunaan modul apakah terdapat perbedaan nyata sebelum dan sesudah penggunaan modul. Hasil Uji Paired Sample T-Test pada Tabel 7. 
DOI: https://doi.org/10.24127/ajpm.v9i1.2443

Tabel 7. Uji Paired Sample T-Test pretest dan postest

\begin{tabular}{lllll}
\hline Uraian & $\begin{array}{l}\text { Std } \\
\text { Dev }\end{array}$ & t & Sig & Ket \\
\hline $\begin{array}{l}\text { Pre-test } \\
\text { Post-test }\end{array}$ & 1,591 & $-15,086$ & 0,000 & $\begin{array}{l}H_{0} \\
\text { ditolak }\end{array}$ \\
\hline
\end{tabular}

Berdasarkan hasil uji T-Test (Paired Sample T-Test) pada Tabel 7 diperoleh $t=(-15,086) \quad$ dengan probabilitas 0,000 ( $p$-value $<0,05)$ yang berarti $H_{0}$ ditolak. Dengan kata lain $H_{1}$ diterima yaitu terdapat perbedaan yang signifikan antara nilai pre-test (sebelum penggunaan modul) dengan nilai posttest (setelah penggunaan modul). Dengan hasil yang diperoleh tersebut yaitu modul teruji efektif dengan kategori kenaikan hasil belajar sedang maka modul dapat digunakan sebagai bahan ajar matakuliah materi bilangan. Hasil penelitian ini sejalan dengan penelitian Pratiwi, Nyeneng, \& Wahyudi (2017) yang menyatakan bahwa modul basis kontekstual teruji efektif dan layak sebagai bahan ajar. Modul yang efektif untuk meningkatkan hasil belajar juga diperoleh dalam penelitian Ismulyati, Khaldun, \& Munzir (2015)

Beberapa faktor penyebab efektivitas penggunaan modul yang pertama yaitu modul sudah divalidasi oleh ahli materi, ahli media, ahli bahasa dan dosen praktikan dan dinyatakan cukup valid serta praktis dan dapat digunakan dalam pembelajaran sehingga dapat meningkatkan hasil belajar. Hal ini sejalan dengan hasil penelitian Lubis, Syahrul, \& Juita (2015).

Kedua, modul disusun dengan disertai dengan contoh kontekstual dengan bahasa yang lebih mudah dipahami sehingga mahasiswa termotivasi untuk belajar sebagaimana respon mahasiswa melalui angket. Hal tersebut sesuai dengan hasil penelitian dari Ardiansyah, Ertikanto, \& Rosidin (2018) yang menyatakan fenomena permasalahan dalam kehidupan seharihari membuat mahasiswa lebih tertarik mengikuti pembelajaran serta Vaino, Jack, \& Miia (2012) yang menyatakan bahwa dengan modul motivasi meningkat signifikan.

Ketiga, modul disusun berdasarkan pembelajaran di kelas terdiri dari capaian pembelajaran mata kuliah dan indikator, apersepsi, materi, aplikasi materi, pemahaman konsep, rangkuman, latihan soal, kunci jawaban, serta refleksi diri sehingga mahasiswa dapat belajar serta mengukur kemampuan masing-masing. Hal tersebut sesuai dengan penelitian Ali, dkk (2010) yang menyatakan bahwa penggunaan modul akan sesuai dengan level kemampuan dan kebutuhan serta langkah masing-masing siswa.

\section{KESIMPULAN DAN SARAN}

Dari hasil penelitian dapat disimpulkan bahwa modul matematika materi bilangan yang dikembangkan efektif untuk proses pembelajaran dengan kategori efektivitas sedang.

Untuk pembelajaran matematika dasar, materi selain bilangan dapat dikembangkan dengan basis kontekstual sehingga akan meningkatkan hasil belajar serta motivasi demi tercapainya pembelajaran.

\section{DAFTAR PUSTAKA}

Ali, R., Ghazi, S.R., Khan, M.S., Hussain, S., Faitma.,Z.T. (2010). Develope and Effectiveness of Modular Teaching in Biology at Secondary Level. University of Science \& Technology, Bannu, (NWFP) Pakistan. Asian Social 
DOI: https://doi.org/10.24127/ajpm.v9i1.2443

Science, 6(9), 49-54. DOI: 10.5539/ass.v6n9p49

Ardiansyah, S., Ertikanto, C., Rosidin, U.. (2019). Pengaruh Penggunaan Modul Pembelajaran Kontekstual Berbasis Multiple Representations Pada Materi Fluida Statis Terhadap Kemampuan Berpikir Kritis Siswa. Jurnal Pendidikan Fisika, 7(2), 265-278.

DOI:10.24127/jpf.v7i2.1489

Badawi, A. I. \& Qaddafi, M. (2015). Efektivitas Penggunaan Modul Berbasis Lingkungan Terhadap Hasil Belajar pesert didik Kelas VII SMP Negeri 28 Bulukumba. Jurnal Pendidikan Fisika, 3(2), 110-116. DOI:10.24252/jpf.v3i2.3716

Gunawan, A. S. \& Widayat, W. (2014). Efektivitas Penggunaan Modul Interaktif Terhadap Hasil Belajar Kompetensi Kelistrikan Power Window Siswa Kelas XI TKR. Jurnal Pendidikan Teknik Mesin, 14(2), 13-16.

Ismulyati, S., Khaldun, I., \& Munzir, S. (2015). Pengembangan Modul dengan Pembelajaran Kontekstual Untuk Meningkatkan Motivasi dan Hasil Belajar Siswa Pada Materi Sistem Koloid. Jurnal Pendidikan Sains Indonesia, 3(1), 230-238.

Lubis, M. S, Syahrul, \& Juita, N. (2015). Pengembangan Modul Pembelajaran Bahasa Indonesia Berbantuan Peta Pikiran Pada Materi Menulis Makalah Siswa Kelas XI SMA/ MA. Jurnal Bahasa, Sastra, dan Pembelajaran, 2(1), 16-28.

Melisa. (2015). Pengembangan Modul Berbasis Penemuan Terimbing yang Valid Pada Perkuliahan Kalkulus Peubah Banyak I. Lemma, 1(1), 21-27. DOI: 10.22202/j1.2015.v1i2.533
Meltzer D. E. (2002). The Relationship Between Mathemathics Preparation and Conceptual Learning Gains in Physics: A possible Hidden Variable in Diagnostic Pretest Score. American Journal Physics, 7. 1259-1268. DOI: $10.1119 / 1.1514215$

Pahriah \& Hendrawani, (2018). Efektifitas Penggunaan Modul Multipel Representasi Berbasis Inkuiri Pada Materi Laju Reaksi Terhadap Pemahaman Konsep Calon Guru Kimia. Prosiding Seminar Nasional di Lembaga Penelitian dan Pendidikan (LPP) Mandala. September 29. 371-374. DOI: http://dx.doi.org/10.1234/.v0i 0.435

Pratama, G. W., Ashadi, A., \& Indriyanti, N.Y. (2017). Efektivitas Penggunaan Modul Pembelajaran Kimia Berbasis Problem-Based Learning (PBL) Untuk Meningkatkan Kemampuan Berpikir Kritis Siswa Pada Materi Koloid SMA Kelas XI. Prosiding Seminar Nasional Pendidikan Sains(SNPS) di Universitas Negeri Surakarta.150-156. Diakses dari https://jurnal.fkip.uns.ac.id/index.p hp/snps/article/view/11406

Pratiwi, R. I., Nyeneng, I. D. P., \& Wahyudi, I. (2017). Pengembangan Modul Pembelajaran Kontekstual Berbasis Multiple Representations Pada Materi Fluida Statis. Jurnal Pembelajaran Fisika, 5(3), 69-79.

Sari, R. N. (2018). Analisis Kesalahan Mahasiswa Teknik Elektro dalam Menyelesaikan Soal Matematika I. Jurnal Absis, 1(1), 28-34. DOI: https://doi.org/10.30606/absis .v1i1.9 
DOI: https://doi.org/10.24127/ajpm.v9i1.2443

Wahyuningrum, T. (2019). Efektifitas Penggunaan Modul Terhadap Peningkatan Nilai Akhir Siswa Pada Pelajaran Bahasa Inggris. $D B B, 14(1), 1-9$.

Vaino K, Jack, H. \& Miia, R. (2012). Stimulating students' intrinsic motivation for learning chemistry through the use of context-based learning modules. Chemistry Education Research and Practice, 13(4), 410- 419.

Yerimadesi, Putra, A., \& Ririanti. (2017). Efektivitas Penggunaan Modul Larutan Penyangga Berbasis Discovery Learning Terhadap Hasil Belajar Siswa Kelas XI MIA SMAN 7 PADANG. Jurnal Eksata Pendidikan (JEP), 1(1), 1-7. 